213

\title{
足関節テーピングがジャンプパフォーマンスに及ぼす影響
}

\author{
小山 桂史 ${ }^{* 1}$, 加藤 知生 ${ }^{* 1}$, 山内 潤一郎 ${ }^{* 2}$
}

\section{Influence of the ankle taping on jump performance}

\author{
Keiji KOYAMA $^{* 1}$, Tomoo KATO ${ }^{* 1}$ and Junichiro YAMAUCHI ${ }^{* 2}$ \\ ${ }^{* 1}$ Toin Univ of Yokohama. Dept. of Sport Technology \\ Kurogane 1614, Aoba-ku, Yokohama-shi, Kanagawa, 225-8503 Japan \\ *2 Tokyo Metropolitan Univ. Dept. of Health Sciences \\ Minami-Osawa 1-1, Hachioji-shi, Tokyo, 192-0397 Japan
}

\begin{abstract}
The purpose of this study was to investigate the effects of closed basket weave ankle taping on the vertical ground reaction force and ankle movment during the contact phase before the take-off in vertical jump performance. Twelve healthy young men performed a vertical jump performance on a force plate without (CON) or with ankle taping (closed basket weave technique: CBW) of the right ankle joint. Vertical jump ability was assessed using two styles of vertical jump with no arm swing: a countermovement jump (CMJ) and squat jump (SJ). From the vertical ground reaction force (GRF), maximum jump height (Ht), vertical impulse (VI), rate of force development (RFD), maximum GRF (GRFmax) during the contact phase before the take-off in jump performance were determined. Also, movement analysis, range of motion ( $\Delta$ ank) and angular velocity (Vank) of ankle joint were caliculated. Ht and RFD, $\Delta$ ank, Vank were significantly lower for CBW than CON in CMJ, but not in SJ. Conversely, VI and GRFmax were not significantly different between the groups in either jump condition. These results suggest that ankle taping impairs countermovement jump performance, due to a decreased ability to rapidly develop large force and plantar-flexion motion on the ground before the take-off.
\end{abstract}

Key Words : rate of force development, countermovement jump, plantar-flexion, closed basket weave

\section{1. 緒}

足関節障害を予防する手段の一つとしてテーピングが挙げられ、多くのスポーツ選手がそれを足関節障害の予 防・再発予防、もしくは障害部位の痛みの軽減を目的として使用している。事実、テーピングは、関節の過度な 可動域を制限して安定性を高め(2)、勒帯の損傷や腱組織の断裂を防ぐ方法、また一時的に痛みを軽減させる方法、 精神的に不安要素を取り除く方法としても有効であることが考えられてきた。足関節テーピングによる足関節角 度の制限は、背屈と底屈の動作範囲がそれぞれ 2 度、10 度狭くなることが報告されている(6)。しかしながら、こ のような足関節テーピングによる底背屈動作の制限は下腿二頭筋の力発揮を低下させ、パフォーマンスの低下を 引き起こす可能性も考えられる。

垂直跳びのパフォーマンスを評価する際の力の指標として、Rate of force development (RFD)や力積(VI), 地面反 力の最大值などが検討され、これらは短距離疾走能力と相関関係が認められる重要な指標としても知られている (8)。足関節テーピングが外的要因から急激な負荷による過度な動作範囲を制限することは、垂直跳び時の RFD のような瞬発的な力発揮を阻害するかもしれない。そこで本研究の目的は、足関節テーピングが垂直跳びの離地

\footnotetext{
${ }^{* 1}$ 非会員, 桐蔭横浜大学 (T225-8503 神奈川県横浜市青葉区鉄町 1614)

"2 非会員, 首都大学東京 (T192-0397 東京都八王子市南大沢 1-1)

E-mail: koyakei@toin.ac.jp
} 
前の足関節底屈動作と力発揮に及ぼす影響を検討した。

\section{2. 方法}

\section{$2 \cdot 1$ 被験者}

健常な男性 12 名(年齢, $20.2 \pm 1.3$ 歳, 身長, $1.76 \pm 0.05 \mathrm{~m}$, 体重, $66.1 \pm 6.1 \mathrm{~kg}$, 平均值 \pm 標準偏差)が本研究に参加し、 1 年以内に下肢の障害の既往暦が無く、足関節テーピングの習慣も無い者であった。

研究の開始に先立ち、被験者には実験の本実験の目的，内容，危険性の説明を行い、同意を書面により得た。 本研究は桐荟横浜大学の倫理員会で承認され、ヘルシンキ宣言の規則に則って実施された。

\section{$2 \cdot 2$ 足関節テーピング}

本研究の足関節テーピングは先行研究(5)の方法に基づいてクローズドバスケットウィーブ法が用いられ、その 方法はヒールロックとフィギュアエイトを組み合わせて実施された。

\section{$2 \cdot 3$ 垂直跳びのパフォーマンスの測定}

垂直跳びは、下肢の反動を用いた垂直跳び(CMJ)と用いない垂直跳び(SJ)の 2 種類によって評価された。実施す る前に、被験者には反射マーカを膝関節中心および外果，第五中足骨に貼付し、垂直跳びの動作を右矢状面から 高速度ビデオカメラ(Nac 社製, Japan)で撮影した。ビデオカメラの設定は、撮影スピード毎秒 125 コマ, 露出時間 $1 / 250$ 秒とした。

\section{$2 \cdot 4$ データ分析}

垂直跳び時の GRF の分析方法は先行研究(3)に基づいて実施された。GRF から滞空時間 $($ Tair $)$ が算出され、身 体重心の離地時の初速度 $(V v)$, 跳躍高 $(H t)$, 力積 $(V I), \mathrm{RFD}$ はそれぞれ方程式(1), (2), (3), (4)によって算出 した。

$$
\begin{aligned}
& V v=\frac{1}{2} \cdot \text { Tair } \cdot g \\
& H t=V v^{2} \cdot(2 g)^{-1} \\
& V I=m \cdot a \cdot \Delta t_{1} \\
& R F D=(G R F \max -G R F \text { mini }) / \Delta t_{2}
\end{aligned}
$$

各方程式に使用した $\mathrm{g}, \mathrm{m}, \mathrm{a}, \Delta t_{1}, \Delta t_{2}$ はそれぞれ重力加速度 $\left(9.81 \mathrm{~m} / \mathrm{s}^{2}\right)$ および質量, 加速度, 時間変化を表す。

$\Delta t_{1}, \Delta t_{2}$ はそれぞれ GRF の最小值(GRFmini)から離地時まで、最大值(GRFmax)までの時閒変化であった。

膝関節中心および外果, 第五中足骨の反射マーカの 2 次元座標置を、動画分析ソフト(Frame-DIASIV, DKH 社製) を用いてデジタイズすることによって求め、それらの座標值から余弦定理によって足関節の角度および角速度を 算出した。その後、動作開始から離地までにおける足関節の角度変化量 $(\Delta a n k)$ と最大角速度 $($ Vank $)$ を算出した。

これらの測定項目の平均值は、垂直跳びの跳矅高が最大であった試技と最低であった試技の 2 試技を除いた 3 試技で算出された。その後、その平均值を $\mathrm{CBW}$ と CON の条件間で比較することによって、テーピングの効果を 検証した。

\section{$2 \cdot 5$ 統計}


全ての測定数值は平均値土標準偏差で表した。それら測定項目の CBW と CON との統計的な比較には、対応あ りの t-test を用いて、有意性の判定にはいずれも5\%未満を採用した。

\section{3. 結 果}

測定項目の平均值と標準偏差は、表 1 に示された。CMJでは、Ht と RFD， $\Delta a n k ， V a n k$ は CBW の方が CON と比較して、それぞれ 4.0 $3.7 \%, 13.0 \pm 10.0 \%, 19.0 \pm 13.5 \%, 16.7 \pm 37.6 \%$ 有意に低值を示した。一方、SJでは、Ht と RFD，Vank は条件間に有意な差は認められなかった。

Table 1. Variables associated with vertical jump performance.

\begin{tabular}{|c|c|c|c|c|c|c|c|}
\hline & \multicolumn{3}{|c|}{$\mathrm{CMJ}$} & \multicolumn{3}{|c|}{ SJ } \\
\hline & & CBW & $\mathrm{CON}$ & p-value & CBW & $\mathrm{CON}$ & p-value \\
\hline $\mathrm{Ht}$ & (m) & $0.37 \pm 0.07$ & $0.38 \pm 0.07$ & $<0.01 * *$ & $0.31 \pm 0.05$ & $0.31 \pm 0.05$ & 0.427 \\
\hline GRFm & $(\mathrm{N} / \mathrm{kg})$ & $21.6 \pm 2.2$ & $22.1 \pm 2.9$ & 0.180 & $23.7 \pm 2.4$ & $23.6 \pm 2.1$ & 0.892 \\
\hline VI & (Ns/kg) & $10.4 \pm 1.2$ & $10.1 \pm 1.1$ & 0.103 & $5.7 \pm 0.4$ & $5.7 \pm 0.5$ & 0.692 \\
\hline RFD & $(\mathrm{N} / \mathrm{s} / \mathrm{kg})$ & $34.3 \pm 20.0$ & $40.1 \pm 22.8$ & $<0.01 * *$ & $59.7 \pm 19.4$ & $57.6 \pm 15.5$ & 0.551 \\
\hline$\Delta$ ank & (deg) & $56.7 \pm 8.1$ & $66.5 \pm 6.6$ & $<0.01 * *$ & $51.3 \pm 9.2$ & $60.9 \pm 7.7$ & $<0.01 * *$ \\
\hline Vank & $(\mathrm{deg} / \mathrm{s})$ & $329.9 \pm 140.0$ & $382.7 \pm 187.0$ & $<0.05 *$ & $418.7 \pm 188.1$ & $475.3 \pm 177.0$ & $<0.08$ \\
\hline
\end{tabular}

Values are means $\pm \mathrm{SD}$. CMJ = counter movement jump, $\mathrm{SJ}=$ squat jump, Ht $=$ jump height, GRFmax $=$ maximum ground reaction force, $\mathrm{VI}=$ vertical $\mathrm{impulse}, \mathrm{RFD}=$ rate of force development, $\mathrm{CBW}=$ with ankle taping, CON = without ankle taping, ** denote a significant difference between $\mathrm{CBW}$ and $\mathrm{CON}$ at $\mathrm{p}<0.01$.

\section{4. 考察}

足関節テーピングが CMJ の跳躍高を低下させた一つの要因として、RFD の低下が考えられる。RFD は身体を 加速させる際の力発揮に関係する重要な指標で(4)、垂直跳びの跳躍高と RFD との間には非常に高い正の相関関 係も示されている(8)。本研究の結果とこれらの先行研究の結果を踏まえると、足関節テーピングによる CMJ の 跳躍高の低下は、離地直前の瞬発的な力発揮の低下によって引き起こされたことが示唆された。

また足関節テーピングは他の関節の力発揮へも影響を及ぼしたかもしれない。垂直跳びのような多関節運動で は、身体を構成する各関節の協調性が地面に対して大きな力発揮を可能にすることが知られており、関節の協調 性が重要であることが示唆されてきた (1)。垂直跳びでの下肢の力発揮は、足関節の貢献度が 20-35\%を占め(7)、 それ以外の貢献度には膝関節や股関節が関与している。本研究では、足関節テーピングは垂直跳び時の足関節の 底屈方向への可動範囲および角速度を低下させた。これらの低下は膝関節や股関節の協調性に影響を与え、これ らの関節回りの筋群の力発揮を低下させた可能性が考えられる。しかしながら、本研究では足関節の動作分析の みを実施しているため、下肢関節間の協調性への影響については不明である。したがって、足関節テーピングに よる底屈方向への動作制限が下肢関節閒の協調性に及ぼす影響については、今後の課題として検討するべきであ ると思われる。

\section{5. 結 語}

足関節テーピングは、特に反動を伴う垂直跳びにおける接地中の足関節の底屈動作を制限し、離地前の瞬間的 な力発揮を低下させ、跳躍高を低下させることが明らかとなった。

\section{文献}

(1) Cordova, M.L., and Armstrong, C.W., "Reliability of ground reaction forces during a vertical jump: implications for functional strength assessment", J Athl Train, Vol. 31, (1996), pp. 342-345. 
(2) Javier, A.V., Luis, M.A., Manuel, F.R., Amador, J.L., Marta, M., and Xavier, A., "Ankle taping does not impair performance in jump or balance tests", Journal of Sports Science and Medicine, Vol. 7, (2008), pp. 350-356.

(3) Kubo, K., Kawakami, Y., Fukunaga, T., "Influence of elastic properties of tendon structures on jump performance in humans", J Appl Physiol, Vol. 87, (1999), pp. 2090-2096.

(4) Moir, G., Button, C., Glaister, M., and Stone, M.H., "Influence of familiarization on the reliability of vertical jump and acceleration sprinting performance in physically active men”, J Strength Cond Res, Vol. 18, (2004), pp. 276-280.

(5) Paris, D.L., "The effects of the Swede-O, New Cross, and McDavid Ankle Braces and adhesive ankle taping on speed, balance, agility, and vertical jump", J Athletic Training, Vol. 27, (1992), pp. 253-256.

(6) Pienkowski, D., McMorrow, M., Shapiro, R., Caborn, D.N., and Stayton, J., "The effect of ankle stabilizers on athletic performance. A randomized prospective study", Am J Sports Med, Vol. 23, (1995), pp. 757-762.

(7) van Soest, A.J., Roebroeck, M.E., Bobbert, M.F., Huijing, P.A., and van Ingen Schenau, G.J., "A comparison of one-legged and two-legged countermovement jumps", Med Sci Sports Exerc, Vol. 17, (1985), pp. 635-639.

(8) Yamauchi, J., and Ishii, N., "Relations between force-velocity characteristics of the knee-hip extension movement and vertical jump performance”, J Strength Cond Res, Vol. 21, (2007), pp. 703-709. 